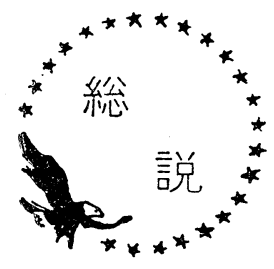

石油（原油）の起源をたどるとはるか 3 千年の昔に さかのぼるが，人類社会に広く用いられ始めたのは， 1800年（江戸時代中期）以降である。すなわち，それ まで注原油そのものを使用して燃料その他使用して はいたが，1848年にイギリスで，1853年にはアメリカ で，初放て灯油を得ることに成功している。日本にお いては，1300 1400年（足利時代）ごろ越後地方で, 露頭原油を汲んでこれを灯火伎用し，悪臭と煤煙に 悩まされていたようであるが，1852年（嘉永 5 年）原 油の単独蒸留により灯油を得ることに成功している。



図 1 わが国最初の原油蒸留釜

これは図 1 亿示すごとく釜に原油を満たし，下方より 加熱する。加熱により発生した油蒸気は，釜の上部に さかさまに置かれた飯焚釜の内側で凝縮し，内壁を伝 わつて流出口から出る仕組となっていた。しかしこの 灯油を標詰にして遠方に送ると到着時には半減してい ることがしばしばあつた。それは多量の揮発油を含有 した灯油であるためで，またそれ故しばしば火災の原 因ともなつた訳である。一時東京ではその危険性を重 視して使用禁止の布告をしたこともあつたが, 輸入灯 油を混合することによつてようやく国産の灯油を使用 することが可能な状態であつた。1884年(明治17年)に 至り国産純粋灯油（火止油と称す）が製造された。す なわち, 揮発油, 残さ油を分けかつ灯油を精製（硫酸
洗浄, 骨炭弓過) することに成功したものである。そ してこの火止油が輸入灯油に比較し, 安価で, 品質も お拉む称抗し得る程度のものであつたため, 次第に 広く用いられるようになり, 灯台用灯济にも公式に採 用され，さきの国産灯油の使用禁止布告も撤回される ようになつた。

ところぶ，ここに意外な問題が潜在していたのであ る。すなわち不油より採取される灯油以外の揮発油, 重油（軽油分は抢そらく灯油, 重油飞混合されていた ものと思われる) の処置であつた。これらの油の用途 はほとんどなかつたので, 初期のころは工場附近の溝, 川に流していたが，少量の場合は問題とならなかつた であろらがここれが多量にないば当然大きな間題とな つた。今でいら公害のはしりであつたのである。一部 の石油工場では, 万年桶と称する底なしのタンクを地 中に埋的，これに流し込んで地中に浸み込ませる方法 によつて, わずかに周囲の攻撃をのがれていたような 状況であつた。

1893年（明治26年）に至り, 揮発油から植物油の抽 出用溶剤の製造に成功し新しい用途が開拓された。一 方同じころ重油を原油蒸留用燃料に用いる試みが研究 された。それまでの原油蒸留用燃料は薪, 石炭であつ たが，原油 $200 l$ を蒸留するのに石炭代 2 円を要した が，重油では12銭ですむことがわかつた。もつとも当 時の重油は廃物同樣で 1 円 $/ 1 \mathrm{kl}$, とし, 石炭 6.7 円 $/ \mathrm{t}$ と して計算している,また精製灯油はこのころ 100 円 $/ \mathrm{k} l$ 程度であつた。当時の重油燃焼法は, 燃燒室内に鉄血 を置き, その上にパイプで少量の重油を送り点火, 加 熱するものであつた。本法は重油の有効利用上画期的 なものであつた故, 大小数多くの製油所はすべてこの 方法を採用した。ところが方法が幼稚なため不完全燃 燒が著しく, 煙突よりのばい煙ははなはだしく，住民 よりの猛反対が起つた。そのため県令（主として新潟 県長岡附近に製油所が集つていた）により重油の燃料 油としての使用を禁止されることとなつた。

翌年この燃焼方法の改善研究が完成し, スチームに より重油を噴霧して燃焼させばい煙が発生しない方法 
が発明され，次第に広く用いられるようになつた。こ れが現在全国で用いられている重油然焼法の唁矢であ る。

これよりさき，すでに1885年（明治18年）亩京に電 灯第 1 号がつき, 以後その数も次第にふえ, 石油ラン プに代わつて夜の世界は電灯に置き変えられるすう勢 となってきた。1907年（明治40年）以降，大都市では 電灯がふえ, 石油ランプは減少の一途をたどるように なつたが，地方ではまだ充分電灯の恩恵に浴するよう にはならなかつた。一方軽油は1900年 (明治35年)ご ろから農作物の害虫距除用として利用され始的た。ま た1907年（明治40年）ガソリン自動車の国産第 1 号が 生れて, 溶郕用としてのガソリンが内燃機联用として その使命を変えつつあつたのである。

第 1 次世界大戦以降国内の工業化之軍備抾镸にとも なつて, 石油製品, 特にガソリン, 重油の需要は次第 に堌加し，装置上からみてもガソリン製造用各種重質 油分解装置, 潤滑油製造用減圧蒸留装置が設置され, 昭和 5 年には本格的パイプスチルと称するフォスター 式原油蒸留装置が新設された。また昭和 13 年〜昭和 15 年ごろにかけて，それまでは小規模低級潤滑油の製造 はシュルツ式減圧蒸留装置によつて行なわれていた が，高級潤滑油の国産化の要望に沿つて, 溶剂脱ろう, 溶剤精製装置が輸入され稼動するようになつた。

第 2 次世界大戦前あるい弾戦時中の石油精製工業は 原油不足もあって，いかにして代用品を效率よく，多 量に得るが努力が傾けられた。人造石油の製造, ガ ソリンへのアルコールの混入, 松根油の製造, 木炭ガ スの篝造なぞがそれであるが，いずれも大きな効果を 得ることなく終わつた。

また戦争前までは, 電力のエネルギー源には水主火 従の原則があつて, 渴水期や夕方のピーク時には不足 分を火力発電によつて補ら方式であつた。ところが戦 後電力需要ののびにつれて, 水源の開発の限界などか ら次第に火主水従の傾向に移行するようになり，それ につれて電力用重油の需要が増えて行つた。最近では 年間1500 2000万 $\mathrm{kl}$ （全石油に対し15\%程度）に達し 石油製品の大きな部分を占めるようになつた。

一方石油化学用原料としてのナフ少, LPG成分, あ るいは自動車用, 工業用, 家庭用としてのLPG（いわ ゆるプロパンガス) または家庭用燃料としての灯油な ぞの需要が新しい方面としてのび，ここ $1 \sim 2$ 年の間 に総石油製品の国内需要は年 1 億 $\mathrm{k} l$ を越えるものと推 定されている。このような旺盛な需要に応ずるため石 油精製業界では各種設備の増強, 新設, 改善が相次い
で行なわれ，発展してきている次第である。

以下これら設備の現況と，それに至る経過，ならび にそれらに付随する各種の問題について記述する。

\section{I . 蒸留, 分解のプロセス}

原油はだいたい図 2 に示すような沸点範図にあり， 炭化水素の混合物 (イたウ分, 窒素分之の他の不純物 若干を含む)であるため，石油精製プロセスの第 I段 階は蒸留操作で始まる。すなわち軽油分までを分別す る常圧蒸留装置，重油分をさらに沸点範囲に応じて分



図 2 石油留分沸点範囲

別する減圧蒸留装置がある。また熱分解装置, 接触分 解装置, 水素化分解装置などで製造された各種炭化水 素をそれぞれの製品に分けるためにも蒸留塔が用いら れている。

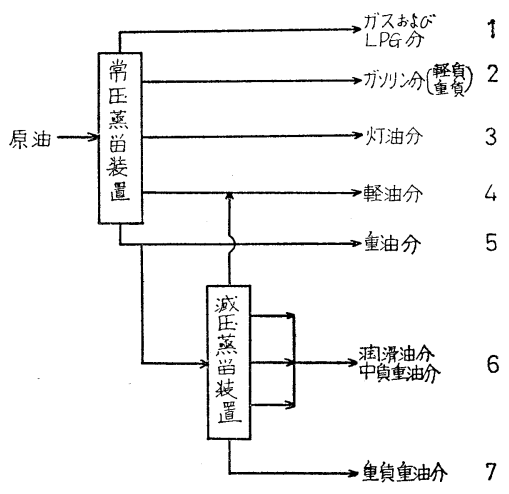

図 3 常圧, 減圧蒸留装置

蒸留塔（精留塔）に擞多くの棚段（トレー）が内 蔵されている。初期のころは舟型または泡鐘型（図 4) であつたが，最近では精留効果と，圧損失減少を衫ら 




図4泡镜型トレー

つたシーブ，フレキシ，リップル，バラストなど幾つ 汃の棚段が研究開発され，実用に供されている。

分解プロセスは図 6 のように大別して 3 種類と考え られるが，最近は水素化分解装置が多く建設されてい るようである。1昨年ごろまでは LPG の需要増加量 功いちじるしく，価格も堅調であつたため LPG 製造 用水素化分解装置が 2,3 建設されたが，それらが稼 “動するころになつて, 輸入による供給能力が増加し, 価格の低下がいちじるしく，タイミングのずれがあつ たよらである。しかし水素化分解による製品は熱分 解, 接触分解による製品より安定性のよい良質な製品 が得られる。

分解プロセスとはいささか趣を異にするが，ガソリ ンの改質法がある。原油蒸留によつて得られる直留ガ ソリンは一般に不純物が多く, 低オクタン価であつて そのまま製品ガソリンとして使用するのには不適当で ある。その質的向上を計るために水素気流中で水素化 分解反応, 脱水素環化反応, 異性化反応を起させる が，脱水素環化反応によつて水素が多量に得られるの で，これを利用して水素化分解，水素精製の水素源と して使用し得る。また製品としての改質ガソリンには 芳香族炭化水素が含まれているので, これらを分離し て芳香族化学製品として利用することが可能である。
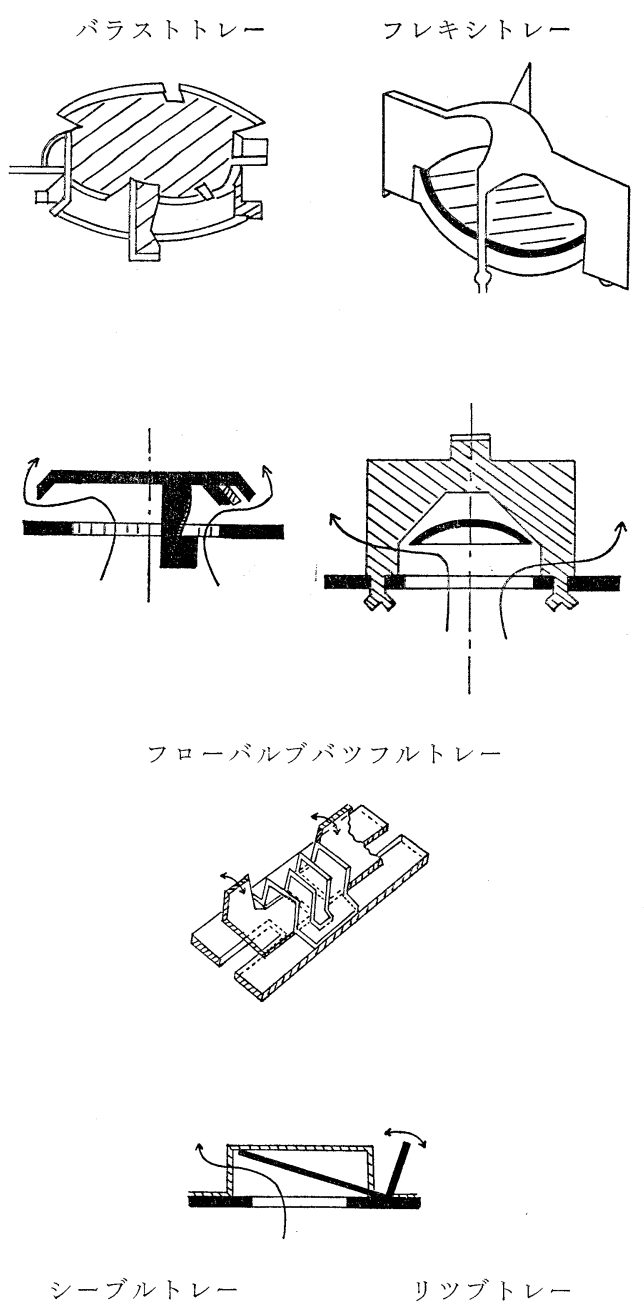

リツブトレー


図 5 各種トレー 






図6 分解プロセス（註：○印で围んだ 番号注図 3 と対照)



（低オクタン価）

(高オクタン価)

図7 改質プロセス

\section{II 。潤滑油製造プロセス}

潤滑油製造の一般的プロセスを図 8 に示す。

潤滑油は用途に応じて種類が多く, 粘度の低い軽油 程度のものからギヤー油, シリンダー油のごとく常温 で半固体のごときものまで広範囲である。潤滑油原料 岋まず常圧蒸留装置残さ油を減圧蒸留装置で $3 \sim 4$ 種

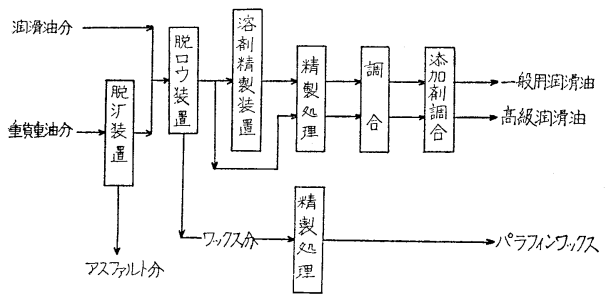

図 8 潤滑油製造プロセス
類の留出油亡残さ油に分ける。留出油は直接脱ろう装 置, 溶剂精警装置でそれぞれろう分, 不安定物質を分 離し, 粘度指数の向上を計る。最後に龇製処理調合を


れるかなり重質の潤滑油原料は, 残さ油中のアスファ ルト分, ピッチ分を除去するた的に脱ろう装置, 溶剂 精製装置で処理する前に脱れき装置でこれらを分離す る。

最近の傾向としては

（1）従来の化学薬品（硫酸, か性ソーダ, 精擎用 白土）による精製に代わつて水素精製法が採用されつ つあこさ

（2）内燃機関，その他の機裁の性能向上にともな つて高性能, 長寿命の潤滑油の要望が高まり, 精䡈度 の向上, 各種添加荗の混入

などが実施されるようになつてきている。

潤滑油褩造プロセスで副生するろう（パラフィンワ ックス）の需要も増加の一途をたどつている。これま での需要沈うそくの他わずかに加工紙用としてであ つたが, 近年容器と流通機構の変化にともなつて, 紙 コップ, 包装紙, 冷凍食品, 野菜用ダンボール, 液体 食品用容器など加工紙部門の需要が急増したためであ り，また量的にはわずかであるがチューインガム，コ ルク透浸材などにも用いられている。このように多方 面に使用されるにつれ品質に対する要望も多方面にわ たり，それぞれの用途に応じた性状を有する品物を供 給しなければならなくなつてきている。

\section{III. 石油化学用原料}

最大の原料はエチレン分解用ナフサである。年 10 万 $\mathrm{t}$ を製造するエチレン分解装置でナフサに対するエチ レンの収率が 20 wt. \%とすれば 年 50 万 t のナフサを 消費することとなる。このナフサは主として常在蒝留 装置よりの直留ガソリンである。

その他分解装置より製造される分解ガス中に含まれ る $\mathrm{C}_{3}, \mathrm{C}_{4}$ 留分も適当にこれらの成分を分離して石油 化学用原料として利用されている。しかし量的にみれ ば，前述のナフサに比較してはるかに少ないものであ る。

\section{IV. 補修, 修理技術}

定められた能力の設備で生産量を多くするためには 必然的に装置の稼動率を上げなければならないことは 明かである。そのために

（1）装置の連続運転期間をできるだけ長くするこ と

（2）定期修理期間をできるだけ短かくすること 
につきる。このための補修，修理技術の向上が今日ほ ぞ重要視されているときはない。

またこれらの実行によつて単に装置の稼動率が上が るだけではなく，補修，修理費の節約と製品原価の低 減といら企業採算の面に貢献することにもなるのであ る。すなわち装置の定期的, 非定期的たるを問わず, その運転停止による損害は

（1）製品, 半製品の生産量の減少

(2) 運転停止操作による損失

人件費，動力費, 燃料費, その他の熱の損失, 規格外製品の生産

（3）修理, 点検, 分解, 掃除などの工事費

(4) 運転開始操作による損失

(5) 間接的損害

生産計画, 修理計画, 営業計画の変更による 損失

などが考光られ，金額的にみても決して少ないもので はなく, その他需要家に対する信用を失うといら無形 の損失も招来する。

まず第一に, 装置の連続運転期閒を可能な限り延長 し得るよう, 装置新設に当つてはこの点を充分考虑し て機器の材質, 構造, 予備機器の設置を考慮する。第 二に定期修理期間中に注次期定期修理時まで連続運転 が可能なよう適切な点検, 修理を行なう。第三に定期 修理期閒を最短にするため重点的工事を進めるととも にCritical Path Scheduling を最大限に活用してNeck Point の除去に努める。第四に運転中は過度にわたら ない Preventive Maintenance を行ならこと, 第五に 機器, 設備の故障, 破損の予知と定期修理時の重点工 事を予測するため強力な On Stream Inspection を行 ならこと。第六に運転中故障, 破損, 浑油が起つたと きはあらゆる応急処置法を駆使して装置の予定外運転 停止を回避するよう努力する。第七にBreakdown Ma intenance を推進して定期修理期間中の工事量削限に 寄与させること。第八に日常の装置運転操作中に各種 機器保全操作作業を織り込んで連続運転期間の延長に 努めること。第九に従来の運転停止操作, 運転開始操 作を再検討してこれらに要する時間, 動熱費の低減に 努めること。

など, 運転担当者, 修理担当者, 設計担当者が一体 となつて努力している。そのためかつては連続連転期 間が精々数ケ月のプラントも最近では 1.5 年あるいは 2 年にのび，定期修理期間も $2 \sim 3$ 週間を出ないよう な成績を得ることができるようになつた。しかし外国 でのある装置では連続運転 1, 400 日以上といら記録も
あり，さらに関係者の一層の努力が望まれている。

あわせて, 最近の労衝力不足は装置の建設費, 修理 費の高騰に顕著にあらわれているので, この方面の費 用節減すなわち工事量の削限と能率のよい工事実施が 緊要な課題となっている。

\section{$\mathrm{V}$. 公 害 対 策}

石油精製工業は他の工業に比較して公察生源とし ての地位は高いとはいえず，むしろそのことよりも公 害発生源となるべき燃料の供給源として世間の注目を あびているのではないかと思われる。

供給源の一つとして重油があげられる。現在一般 C 重油中のイオウ分は $2 \%$ 台である。将来はこのイオウ 分を $1 \%$ 台に引き下げられるような動きがあるため, 石油精製業界としては重油の低イオウ化が緊急の課題 としてとり上げられるようになつていることは周知の とおりである。

重油の脱硫法には金属酸化物による方法, バクテリ ヤによる方法, 水素化脱硫法などが考えられている が, 現在水素化脱硫法が工業化され得る唯一の方法と 考えられる。これは重油調合材料としての各種軽油分 の脱硫と，残さ油を直接脱硫する方法があるが，調合 材料の脱硫では C重油中のイオウ分降下にも限度があ るようである。残さ油の脱硫法として発表されている プロセスは Isomax 法 (UOP, CRC) Gulf HDS 法 (Gulf fResearch \& Develop. Co.) H-Oil 法 (HRI, Cities Service Co.) などがある。これらの方法に共 通していい得ることは

（1）重質油中のイオウ分は高分子化合物であるた め反応条件をかなり莀酷にするためカーボンの生成が はなはだしい。

（2）残さ油中の金属, カーボンの含有量が多いた め触媒の活性低下がいちじるしい。それゆえ耐金属, 耐カーボン触媒の開発が望をれる。さもないときは活 性の低下した触媒の入れ変え, 補充を多量に, ひんぱ んに行なわなければならない。

（3）多量の水素を必要とするため（400-1000 $\mathrm{SCF} / \mathrm{Bbl})$ 水紊発生装置とその原料が必要である。

（4）残さ油中にはイオウ分, 金属の他任空素, 塩 素，その他の不純物が含有されているが，これらが高 温高压下 $\left(400^{\circ} \mathrm{C}\right.$ 以上, $100 \mathrm{~kg} / \mathrm{cm}^{2} \mathrm{~g}$ 以上) で塩化水素, 硫化水素, アンモニアなどを生成して, 装置の腐食, 水索ぜいせい, の原因となるほか, 異物の生成により 熱効率の低下，閉塞をおこす危険がある。

（5）除去されるイオウは単体イオウとして回収さ れることになるであろらが, この場合 50,000 BPD の 
残さ油を処理する装置で $1 \%$ イオウ分を下げても 1 日 $100 \mathrm{t}$ 近いイオウが生産されることになり,この有効利 用と処置を考えなければならない。

以上のように, 残さ油の直接脱硫についてはいろい ろと問題が残されているようである。

石油精製工場としての直接の公害問題は, 他の各種 工場と同様, 煙突排ガス, 廃水, 臭気, 騒音である。 煙突の排ガスについては, 排ガスの脱硫（亜硫酸ガス 除去）装置を有する工場以外はやはり燃料中のイオウ レベルの降下を計る以外, 適切な方法はないようであ る。

精製用燃料は大別して重油と分解, 改質ガスである。 重油の低イオウ化は前述の残さ油直接脱硫装置を有す る石油精製工場が現在国内には 1 ケ所もないため, 主 として重油調合材料の間接脱硫 (灯軽油脱硫装置) に よる場合と, 低イオウ原油 (イラン (ヘビー) 原油, ミナス原油, デュリ原油など) よりの重油を使用する 場合である。

分解, 改質 (灯軽油の脱硫装置を含む) ガスはその ガスを処理して主として硫化水素を除去するが，その 代表的プラントがイオウ回収装置で, この装置によつ て製造された精製ガスはほとんどイオウ分を含有しな い。イオウ回収装置では硫化水素を直接酸化してイオ ウにする 1 段法 $\left(3 \mathrm{H}_{2} \mathrm{~S}+3 / 2 \mathrm{O}_{2} \rightarrow 3 \mathrm{H}_{2} \mathrm{O}+3 / 2 \mathrm{~S}_{2}+145 \sim\right.$ $173 \mathrm{kcal}$ ) と一度硫化水素を水と亜硫酸ガスにし(燃焼 による), この亜硫酸ガスと硫化水素を反応させてイオ ウにする 2 段式がある。 $\left(\mathrm{H}_{2} \mathrm{~S}+3 / 2 \mathrm{O}_{2} \rightarrow \mathrm{H}_{2} \mathrm{O}+\mathrm{SO}_{2}+\right.$ $124 \sim 138 \mathrm{kcal}, 2 \mathrm{H}_{2} \mathrm{~S}+\mathrm{SO}_{2} \rightarrow 2 \mathrm{H}_{2} \mathrm{O}+3 / 2 \mathrm{~S}_{2}+21-35 \mathrm{kcal}$ ) 現在実装置に用いられているのはほとんで 2 段式であ る。これは原料ガスの $1 / 3$ を廃熱ボイラーに送つて燃 焼させて亜硫酸ガスとし, このガスと廃熱ボイラーを 通らない残りの $2 / 3$ の原料ガス（硫化水素を多量に含 む)を混合して触媒層に送りイオウを得る方法である。 この精製ガスを燃料に使用することによつて煙突の排 ガス中の亜硫酸ガスを大巾に低下させることが可能と なった。

元来大気污染防止を含む公害基本法の趣旨は, 住民 の常住する地表面近くの大気の清浄性を強調している 点から考え, 石油精製工場においては環境基準を重視 している。原因となる煙突排ガス中の有害物質の排出 基準を定めても, 排出源の密集度, 風向, 風速, 天 候によつても環境の悪化度は大巾に変わることは明か である。それゆえ現在では然料中のイオウレベルを下 げると同時に煙突の高さ，ガス排出速度を上げてその 拉散を計るような方向に努力が払われている。
石油精製工場に扔ける化学薬品その他の水污染源注 さほど多種類にもわたらず, 量的にも少ないので, こ れらの処置はそれぞれに応じて適宜行なわれているの で大きな問題となることは少ないが，工場よりの排水 中に含まれる油分が最も問題である。排水中の油分規 制は現在10-20p.p.m.であるが, 将来 $4-5$ p. p.m. に下げられる可能性がある。現在の重力式油分離槽で は大体 10p.p.m.が限度で, それ以下にするためには 特別な方法を採用しなければならないと考えられここ の方面の研究も目下盛んに行なわれている。

\section{表 1 污水, 廃液の基準}

水域の区分 $\mathrm{A}$ 水域 $\mathrm{B}$ 水域 $\mathrm{C}_{\text {水域 }}$

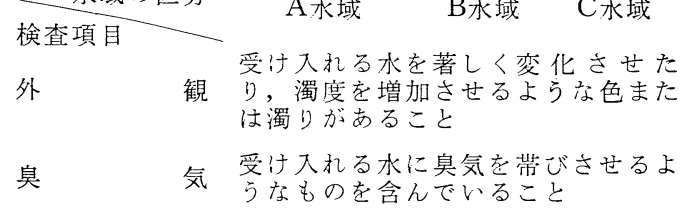

水素イオン濃度 5.8 末満, 8.6 以上

\begin{tabular}{|c|c|c|c|c|}
\hline \multirow{2}{*}{$\begin{array}{c}\text { 浮 遊物 } \\
\text { 質 } \\
(\mathrm{mg} / \mathrm{e} / \mathrm{l}) \\
(\mathrm{m})\end{array}$} & 明間平均 & 40 & 70 & 120 \\
\hline & 最 大 & 70 & 100 & 180 \\
\hline \multirow{2}{*}{$\underset{(\mathrm{mg} / l)}{\mathrm{BOD}}\{$} & (日間平均 & 20 & 50 & 12 \\
\hline & 最大 & 30 & 80 & 18 \\
\hline \multirow{2}{*}{\multicolumn{2}{|c|}{$\underset{(\mathrm{mg} / l)}{\mathrm{COD}}\left\{\begin{array}{c}\text { 日間平均 } \\
\text { 最大 }\end{array}\right.$}} & 20 & 50 & 120 \\
\hline & & 30 & 80 & 180 \\
\hline
\end{tabular}

油 $\begin{gathered}\text { 脂 含有 } \\ (\mathrm{mg} / l)\end{gathered}$ 量 $\left\{\begin{array}{c}10 \\ \text { 表面に油膜を生じていること }\end{array}\right.$

その他の条件 人または物に害をおよぼす特度の有

A水域：水源となるよらな河川の上流地域 (場所の指定あり)

B " : A.Cの中間と比較的人家の多いところ (場所の指定あり)

C " : 最下流地域。

\section{表 2 ばい煙の基準 (抜すい)}

亜硫酸ガス, 無水硫酸 一般地区 4 日市・横浜地区 一般 施 設 ガス供給業または 石油精製業の用に 供する施設

$\begin{array}{ll}0.22 & 0.18 \\ 0.28 & 0.22\end{array}$

表 $1 ， 2$ に排水，排ガスの規制值を示した。

工場の臭気もなかなかやつかいな問題である。個人 には体臭があり, 各戸には特有の家臭があるように, 工場にも独自の臭気がある。元来臭気に対する感知度, 不快感は個人差が大きいためこれを根本的に解決する には大きな困難がともなう。たとえばわれわれが喫茶 店の前をとおつて馥郁としたコーヒーのにおいをかげ ばよい香りだ一寸のみたいといら快感を味わうが, 年 中このにおいにさらされている隣家の住民にとつては 
たえがたいにおいと感するかも知れない。

工場の臭気対策については以下のように考えてい る。

（1）臭気の調查 発生源を把握するとともに，そ の発生源の臭気がどの程度周囲に影響をおよぼすもの であるかを知る必要がある。

人間の臭気に対する感知度は個人的に大差があると 前にも述べたが，1個人についていえば成人若年者ほ ぞ，健康状態が良好なときほど，空腹時ほど感知度は 高い。また調查は 1 人ではなく数人のグループ（調査 員が平均した臭気感知能力を有するかを調查する）に よる臭気調查チームを結成し，空腹時に，継続的に調 查を実施する。

（2）対策 臭気を発生する個所の除去または臭気 を発生しないようにする発生源対処法，発生源はその ままにして臭気が人間に到達しないように遮断する経 路対処法, 発生悪臭を捕捉消減するか良臭に変える悪 臭物質対処法などがあり，その具体的方法として燃焼 法, たとえば硫化水素としては 0.025 0.1p.p.m.で 人閒が感知し得るが，これを燃焼して亜硫酸ガスとす れば100倍以上の濃度である $2 \sim 3$ p.p.m.にならなけ れば感知し得ないよらなことから悪臭物質を燃焼させ る方法がある。また臭気物質を煙突，ベントなどから 放出分散させる方法, 化学薬品により吸着させる方法 などがあり，個々の場合に応じて対処されている。

その他装置, 機器の運転による騒音の問題, 油タン カーのバラスト中に含まれる油分処理の問題など，石 油精製工場自体解決しなければならない公害上の問題 がいくつか女り，逐次，研究，解決の方向に向つてい る。

\section{III. その他の諸問題}

企業の合理化と原価低減の要望にそつて石油工場は 大型化，自動化の方向に進んでいる。かつては 1 製油 所の処理能力 5 万bbl程度であつたものが最近では $10-$ 20 万b.b.1となり，原油輸送用タンカーも 15 万 $\mathrm{t} ， 20$ 万 $\mathrm{t}$ の巨大化によつて運転費，輸送費の低隇が計られる ようになつた。また工場内では自動化，集中化も進め
られ,これまでは 1 単位操作（たとえば原油蒸留装置, 減圧蒸留装置, 改質装置など) ごとに独立し, その各 プラント間に中間タンク（原料タンク，半製品タンク など）を置くのを慣習としていた。そこでこれらいく つかのプラントを 1 個所に集め，中間にタンクを置か ず直接パイプで連絡するとともに加熱泠却の 2 重操作 を省略して，動熱費を節約するいわゆる Integrated Plant が建設されるようになつた。同時に中央制御室 も 1 個所に集め人員，敷地の節約を計るものである。 このようなプラントの建設によつて同時に機器, 設備 の自動化も大いに促進された。すなわち電子計算機に よる自動制御システム，自動試料採取分析装置，プラ ントの非常事態における自動処置システム，などがあ り, 細部では機器故障時の予備機器への自動切替設備, 油槽の液面, 温度などを計器室で知り得るリモートタ ンクゲージ，調合タンクを省略したオートブレンダー システム, 出荷量, 移送量を自動的に制御記録し伝票 を作成し事務所に送付する装置など，枚挙にいとまが ないほど実用化されている。

しかしこのように各種，多様な仕事がすべて機械化 され自動化されたために弊害も生じている。すなわち 肉体的労㗢に対する不満は従来に比しはるかに少なく なつたが，今度は精神的苦痛を訴える声がおこつてい る。工場運転員は勤務時間中椅子に腰をかけ，簡単な 監視業務に精神をすりへらすといらのである。やはり 工場が自動化され，機械化されても，適当な肉体的労 働と企画的な面も加えた仕事を行ない得るように考え る必要があるのではないかと思つている。

以上広義の石油精製技術の発展の歴史と現況を述べ た。今後石油需要の急速なのびに対処するため, 石油 精製工場の拡充，新設はもちろん，その質の面も，全 産業の技術的進歩にともなつて，大、に改善を要求さ れることと思われる。また工場の立地条件や，日本特 有の地理的条件から，公害対策の樹立と，その処置実 行も急きよ行なら必要に迫られている。過去 100 年間 に目覚しい発展をとげた石油精製技術も，今後は今ま での数倍の速度で発展向上するものと期待している。 


\title{
Trends and Problems in Petroleum Refining Technology
}

\author{
by Takaaki Yamaguchi \\ (Nippon Oil Co.,)
}

SYNOPSIS:-Petroleum Refining Technology, which had started in last century to obtain illuminating Kerosin, has made remarkable progress in this century and future improvements are expected by applications of new technology.

This article explains recent trends and problems in refining technology, ex.

1) distillation and conversion processes, 2) refining processes of lubricating oils, 3 ) petrochemical raw materials, 4) repair and maintenance technics, 5) public nuisances and so on. 